\title{
DISCURSO DE POSSE DO EXMO. PROF. DR. RUI GERALDO CAMARGO VIANA, COMO PROFESSOR TITULAR DE DIREITO CIVIL DA FACULDADE DE DIREITO DA UNIVERSIDADE DE SÃO PAULO.
}

Exmo. Sr. Prof. Dr. Álvaro Villaça Azevedo, Digníssimo Diretor da Faculdade de Direito do Largo de São Francisco,

Exmo. Sr. Prof. Dr. Antonio Junqueira de Azevedo, Paraninfo desta solenidade,

Douta Congregação,

Minhas Senhoras e Meus Senhores,

Acadêmicos de Direito.

Ao subir os degraus desta tribuna assaltam-me sentimentos da mais incontida alegria, por ver realizado o sonho acalentado por toda uma vida.

Não trago a melancolia de Montalverne, por tanto ter esperado para realizá-lo; com efeito, nunca será tarde demais para realizar os sonhos que, na formulação de Platão, terão de ser a última túnica de que há de se despir a minha alma.

Quisera, sim, que tal tivesse ocorrido no florir da mocidade, emprenhada de ânsias e vaidades, na vã suposição de poder reformar o mundo e para que pudesse dar conta aos meus maiores, que em mim depositaram suas melhores esperanças.

Mas o tempo passou e eles cansaram de viver; por certo, em algum ponto do Écran, acompanham e velam pela minha caminhada.

Já não podendo transferir-lhes, materialmente, este galardão, que para mim é uma coroa de louros, deposito-a no altar da família e apresento à minha mãe, orgulhoso, este meu boletim.

Perdoem-me os meus ouvintes, a minha pieguice, mas este é o meu momento.

Ser recebido neste Areópago insigne, depositário das mais nobres e dignificantes tradições da nacionalidade, é benção a que nem ousava aspirar.

Persegui o meu destino, descuidado do resultado da incógnita caminhada; sabia que era necessário caminhar, sem cuidar, porém, para onde me levava o meu destino. 
Tinha um rumo, tinha um norte a defesa da liberdade e a realização concreta do Direito - que aprendi a cultivar nos bancos acadêmicos.

O veículo o trabalho constante e apaixonado lição colhida de meu pai, um libertário que jamais se submeteu a qualquer injunção, um daqueles cidadãos que nunca admitiram receber benesses do Estado, a ponto de impedir que qualquer de seus seis filhos estudasse em escola pública que reputava um favor do príncipe.

Firmei, na divisa Labor omnia vincit improbus, o meu roteiro e exclusivamente do trabalho hauri os frutos, materiais e espirituais, que amealhei na vida.

Ouvindo a formosa oração do professor Junqueira de Azevedo, nesta assentada, mal pude reconhecer no seu bosquejo digno de um Velasquez, minha figura retocada com a pátina da amizade e enfocada com a visão de portador de um grande coração.

Na Academia e na banca do advogado intimorato Raimundo Pascoal Barbosa, iniciei meu aprendizado e meu trabalho na lida do Direito, com ele aprendendo a agir sem temor e sem transigência na defesa das causas abraçadas.

Na Magistratura encontrei o caminho e as condições para a efetivação concreta do Direito, confiando em que nas mãos do magistrado repousa a garantia dos cidadãos.

Nela ingressei, por concurso público, e galguei todos os seus degraus até o Tribunal de Justiça de meu Estado, aposentando-me no cargo de Desembargador.

Penso ter cumprido o meu dever, trabalhando à exaustão, convicto de que, a par da qualidade, a brevidade é condicionante da Justiça, pois é consabido que la justice qui tard devient une injustice.

Mantive, sempre e a qualquer custo, minha pauta de audiências em trinta dias, proferindo as decisões, quando não em audiência dentro da maior brevidade possível.

Nos tribunais, nunca figurei em estatísticas de atraso e, quando instado, votei pela imediata distribuição de todos os feitos existentes na Secretaria.

Não ignoro as dificuldades que assolam o Judiciário, mas a presteza nos julgamentos é problema a ser urgentemente solvido, recorrendo-se antes das complexas e demoradas reformas, desde logo, aos avanços da tecnologia e otimização dos recursos humanos. 
Espera-se que o Executivo proveja os meios materiais indispensáveis, e que os nossos Tribunais, dêem ênfase, ao recrutamento de juízes, cooptando os jovens profissionais capacitados, através de uma política salarial compatível e preparação dos vocacionados em estágios já engajados na Magistratura, como o modelo francês que apresentei ao Tribunal de Justiça de São Paulo, após estágio na École Nationale de la Magistrature, de Paris.

Penso ter cumprido o meu papel, julgando com isenção e com destemor, como compete a todo juiz o qual não tem direito de ser fraco ou titubeante, ornado, pela sociedade e pela cidadania, com garantias especiais de independência intelectual e econômica.

Para exercício dessa independência, não pode o juiz estar sujeito a outra injunção que não sua consciência informada pelo seu contingente moral e intelectual.

Encarnação de um Poder da República, não pode exercê-lo com peias, daí me parecer uma excrescência o propalado "controle externo"

Aliás, fiscalizado ele está, sempre, porque assentado no pódio mais alto como lembra Ruy, ali o juiz está para melhor ser visto e acompanhado, em suas atividades, por toda a sociedade.

Sua atuação, no processo, está sujeita ao crivo do contraditório, exercido pelas partes assistidas de advogados; a atuação do Ministério Público, em casos de peculiar relevância, acrescenta novo controle na aplicação da lei, sem falar na pletora de recursos que, no plano vertical, submete as decisões dos juízes à revisão sistemática.

Essa revisão poderá levar qualquer causa ao Supremo Tribunal Federal, cujos membros são nomeados pelo Executivo com aprovação do Senado, respeitando o equilíbrio de poderes tido por Montesquieu como a pedra de toque da democracia.

Sabido que os juízes são recrutados, hoje, democraticamente, em concursos públicos com a participação da $\mathrm{OAB}$, e formada a composição dos Tribunais com o quinto constitucional, não se poderá apodar de elitista ou enclausurada, a Magistratura.

No ângulo objetivo, a representação interventiva traduz meio eficaz para se obter, a par do controle concreto, o controle abstrato das normas em cotejo à lei fundamental e sua ampliação para controle objetivo em defesa da Constituição, 
agora cometido a plúrimos organismos além do procurador geral, instrumentaliza a sociedade para defesa de seus direitos e obtenção de efetiva atuação do Judiciário.

Não há, pois, mister retrogradar a nefastos procedimentos, de que foi rica a praxis brasileira, bastando lembrar o vergonhoso Decreto n. 19.711/31 que, ditado por "imperiosas razões de ordem pública", determinou o afastamento de Ministros da Suprema Corte por, dentre outros, "motivos de natureza relevante"

Todos sabem que os "relevantes motivos" consistiam em fazer calar Juízes independentes, discordantes da ditadura reinante.

O repetir da história já nos mostra o perigo dos inconformismos despóticos, valendo relembrar recente episódio, em que nosso atual presidente da República quis insurgir-se contra decisão do Pretório Excelso que sobrepôs a Constituição ao interesse econômico perseguido pelo Executivo.

Trazer o controle externo importará ressuscitar a Carta de 1937, com seu famigerado art. 96 que franqueava ao Legislativo repristinar a lei julgada inconstitucional pelo Supremo, reeditando-a em procedimento cassatório da decisão judicial.

Critique-se o Judiciário, reclame-se Justiça mais barata e presentânea, cobre-se punição dos maus juízes, mas sempre preservando os predicamentos da Magistratura que outra coisa não traduzem senão a plena garantia dos cidadãos.

Se na Magistratura angariei a possibilidade de fazer atuar o Direito em sua concretitude, no magistério encontrei a possibilidade da disseminação do bom Direito, transmitindo aos acadêmicos minhas idéias e meus ideais.

Se, como juiz, me sentia à letra da lei, pois a função do magistrado é de fazer atuar o direito existente, como professor me senti livre para criar, para propor reformas e contemplar o direito in fieri, pois o professor é arauto da evolução jurídica e precursor das novas formulações legais.

Vivi, sempre muitas coisas aprendendo e tudo que aprendi, sem avareza transmiti e procuro passar para os meus alunos.

Nestes longos anos de magistério, tenho experimentado a melhor recompensa, a maior alegria de um mestre que é ver-se suplantado pelos seus discípulos.

Vejo-os vitoriosos na Magistratura, no Ministério Público, na Advocacia e no Magistério e nas funções políticas, no Executivo e no Legislativo. 
Esta contemplação, desinteressada e orgulhosa, é a paga que recebem os mestres pelo seu fadário, remuneração incompreensível para quantos só medem o rédito do trabalho pela quantidade de pecúnia recebida.

Foi comigo pródiga a Providência, dando-me sempre o amparo familiar, angariado na companhia da esposa Neide que me incentivou por longos anos e me deu os filhos, Maria Beatriz, Maria Angélica e Rui Geraldo, que participam desta conquista.

Portador de um só coração e dois amores, encontrei Renata, que me trouxe novas venturas e um novo sentido à vida que se renova na criação de Rui Gustavo e Rui Guilherme, não-amadurecidos para entender a liturgia, aos quais dedico a láurea.

Sinto, por fim, para completar tanta fortuna, a palpitante presença, ainda descansando no seio materno, dos meus três netos que, in fieri, já partilham comigo a incomensurável dita.

Enfim, Senhores, por quê tanto labor, tanto esforço para estar aqui?

Porque sempre quis ser um sacerdote da Justiça e, onde melhor altar encontraria para cultuar a Liberdade, senão nesta velha e sempre nova Faculdade?

São Paulo, 20 de março de 1997. 
$=$ 


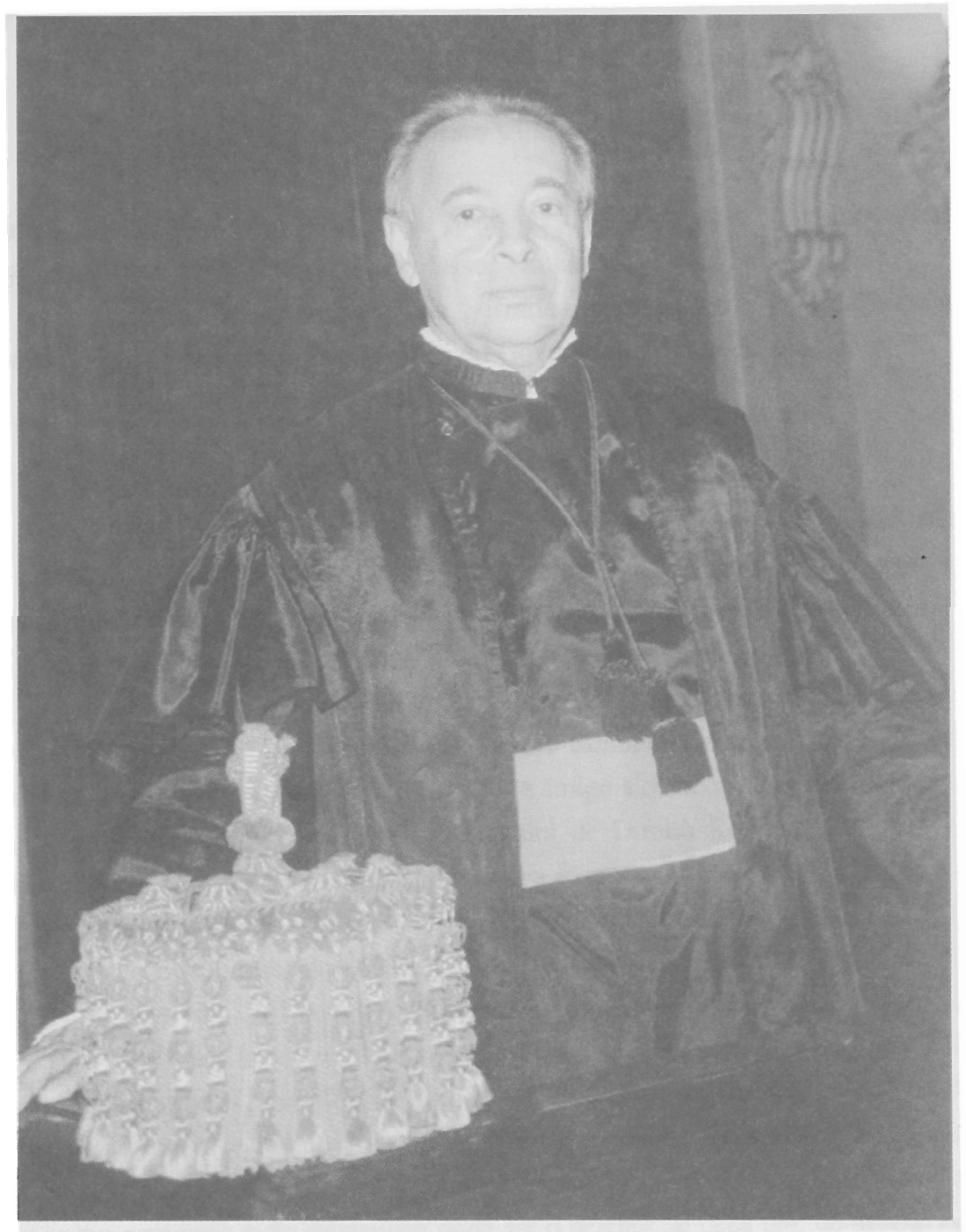

Professor Rui Geraldo Camargo Viana 